\title{
The Women Who Don't Get Counted
}

\author{
Caelan Rathke*
}

ABSTRACT

The current incarceration facilities for the growing number of women, are depriving expecting mothers of adequate care crucial for the child's mental and physical development. Programs need to be established to counteract this.

Keywords: Pregnancy, Incarcerated Individuals, Unequal Care, Postnatal Care, Nursery Programs

\section{INTRODUCTION}

Currently, Diana Sanchez was eight months pregnant when she was arrested for identity theft and put in a prison cell in Denver. At five a.m., two weeks after being incarcerated, she announced to a deputy outside her cell that she was going into labor. Footage from a camera in her cell shows her pacing anxiously or writhing in her bed for the five hours preceding the arrival of her son. She banged on the door and begged for help. All she received was an absorbent pad. She gave birth alone in her prison cell on July 31, 2015, around 10:45 am. At 11:00 am, a prison nurse walked in to cut the umbilical cord and take Sanchez's newborn baby without offering postnatal care. Sanchez was later sent to a hospital, and her baby was separated from her until she was put on probation. In 2018, on behalf of her three-year-old son, Sanchez sued Denver Health and Denver Sheriff Department and won a \$480,000 settlement. ${ }^{1}$

Though many more men are incarcerated than women, the rate of growth of female incarceration has exceeded that of male incarceration for decades. One study estimated that 231,000 women are currently incarcerated in the US, ${ }^{2} 80$ percent of whom are mothers, and 150,000 pregnant. ${ }^{3}$ Another recent study of 1,396 incarcerated pregnant women found that 92 percent had live births, 6.5 percent had stillbirths or miscarriages, and 4 percent terminated the pregnancy. The authors found that there is no system of reporting pregnancy outcomes in US prisons.

There is a noteworthy ethical lapse in mental, emotional, and medical care that threatens the well-being of pregnant women in prison. According to Carolyn Sufrin, "Pregnant incarcerated people are one of the most marginalized and forgotten groups in our country... and women who don't get counted don't count."

* Caelan Rathke, Colorado Christian University

(C) 2021 Caelan Rathke. This is an open access article distributed under the terms of the Creative Commons Attribution License, which permits unrestricted use, distribution, and reproduction, provided the original author and source are credited. 
${ }^{4}$ Poor documentation, visibility, and transparency contribute to the systemic abuse of incarcerated women. Studies document women giving birth alone in cells and shackles in solitary confinement. Their complaints regarding contractions, bleeding, and other pains of labor are often ignored. ${ }^{5}$

\section{Prenatal Care in American Prisons}

Diana Sanchez was not offered any prenatal care after she was incarcerated. And neither she nor her son received appropriate postnatal care. ${ }^{6}$ Sanchez was on medication for opioid withdrawal while pregnant, which could have been detrimental to her baby's health. ${ }^{7}$ There is an unacceptable absence of pre- and postnatal care in most US prisons. A lack of regulation makes the availability of perinatal care unpredictable and unreliable.

Several studies confirmed that there is not a standard for prenatal care for women incarcerated during pregnancy. ${ }^{8}$ Knowledge of the appropriate mental and physical care pregnant women require, addiction support, and support for maternal-infant bonding all exists outside the prison system and ought to be used as a benchmark. At the very least, pregnant women, birthing women, and new mothers should not be placed in solitary confinement or shackled. ${ }^{9}$ In the prenatal arena, depriving an individual of adequate healthcare is not appropriate and could be cruel and unusual.

Only 18 percent of funding in prisons goes to health care for the prisoners. That is roughly $\$ 5.7$ thousand per prisoner, according to an $\mathrm{NIH}$ study done in $2015 .{ }^{10}$ There should be an adequate amount of funding for the health needs of incarcerated pregnant women. By depriving pregnant women of healthcare, the prisons are depriving the fetus of adequate care.

\section{Respect for Autonomy During Incarceration}

Women maintain healthcare autonomy even when incarcerated. The purpose of a prison sentence is retribution for crimes and rehabilitation to prevent reoffending. ${ }^{11}$ The separation of a mother and newborn causes significant developmental and psychological harm to the child and the parent. Parent-child separation does not serve the purpose of retribution or rehabilitation and is authorized only due to prisons' limited space and resources that make it difficult to accommodate children, as well as a state interest in children's best interests or the custody rights of the other parent. When it is possible to keep a family together, prisons should make every effort to do so for the health of the mother-child relationship.

Incarcerated people may become a burden to family or society due to prison medical neglect. For example, diabetes and hypertension, which can occur during pregnancy, can worsen without treatment. The inability to access the care they would otherwise want and need endangers women and poses a burden to the healthcare system after incarceration,

Depersonalizing individuals convicted of crimes must be placed in the context of historical eugenics practices. State-sanctioned sterilization and efforts to prevent women from reproducing were widespread during the early 20th century. ${ }^{12}$ Cases of coerced and nonconsensual sterilization of incarcerated women and men evidence the history of eugenics. ${ }^{13}$ Abortions are offered to some incarcerated women. ${ }^{14}$ However, many incarcerated women are denied the right to see healthcare providers to thoroughly discuss abortion or other options. ${ }^{15}$ Although the abortions are consensual, the quality of consent is questionable.

III. Prison Nursery Programs, "I need something to live for..."

Indiana Women's Prison (IWP), a max security female prison, has a program called Wee Ones that enables women convicted of nonviolent crimes to spend 30 months bonding with their newborn child. It is one of 
eight programs in the country that allows pregnant mothers to spend the last few months of their sentence with their children. It is a voluntary program that allows pregnant offenders a private room in a housing unit. It offers parent education, resources that are accessible after release, and career education.

The program application process and the rules to which women must adhere to remain in the program are stringent. The programs generally have a zero-tolerance policy. Even simply sleeping in the same bed as the child or arguing with other mothers can result in termination from the program. Kara, a pregnant woman incarcerated for drug possession, had a history of abuse in her family and tended to act out in anger against her peers in the program. She was learning how to have healthy reactions to anger when handling her child, but her temper ultimately led to her removal from the program. Her son was placed in foster care, and Kara returned to the regular cells. In an interview before her transfer, she told the camera that Charlie gave her a purpose. With tears in her eyes, she said, "Charlie was my way of life here [...] I need something to live for [,] and I screwed up." ${ }^{16}$

Pregnancy in prison can be a way to improve quality of life for some women. Studies demonstrate that nursery programs improve mental health of the incarcerated women. ${ }^{17}$ The secure attachment of the infant to its primary caregiver promotes healthy development in the child and a bonded relationship with the mother. ${ }^{18}$ The close bond between mother and child in prisons has been shown to decrease recidivism and to reduce the burden on the foster care system. ${ }^{19}$ Women who do not qualify for these programs, or are incarcerated in prisons without them, are separated from their newborn babies and their other children. The disconnect can lead to the child rejecting the incarcerated mother once she is released. ${ }^{20}$

Programs like Wee Ones honor women's autonomy while they are incarcerated. During interviews, the women expressed that although raising a child in that environment is difficult, it was better than not being with their children. While rocking a baby in her lap, one inmate expressed her frustrations with Wee Ones but then paused to express gratitude and said, "After all, it's prison. And prison ain't supposed to be nice." ${ }^{21}$ The ethical issue of autonomy reflects a more difficult dilemma in the prison landscape.

\section{Counter Arguments: Do the Nursery Programs Work for the Children and the Women}

Typically, newborns are taken from their incarcerated mothers within two to three days of birth and sent to live with a relative or placed in foster care. Many women are never reunited with their babies. There is much debate over whether the programs are beneficial to the children. One ethical issue is whether children, as innocents, are being punished either by being in the prison system or by being separated from their mothers.

Skeptics, like James Dwyer, have argued against keeping innocent babies in the custody of incarcerated mothers asserting that there is little evidence demonstrating that the programs rehabilitate the women. ${ }^{22}$ Dwyer commented on the "reckless" hopefulness the programs provide:

"It might, in fact, be the babies distract them from rehabilitation they should be doing instead. [...] They're so focused on childcare and have this euphoria - they think they'll be just fine when they get out of prison and they're not. We just don't know." 23

One study showed that 58 percent of incarcerated women are arrested again after release, 38 percent are reconvicted, and 30 percent return to prison within three years. ${ }^{24}$ Dwyer uses this data to argue that the programs are not worthwhile. However, the data is not limited to the special population that had the prison nursery experience. The data applies to all incarcerated women limiting its applicability. More importantly, 
there is compelling evidence to support prison nursery programs. ${ }^{25}$ The programs do decrease recidivism ${ }^{26}$ and prison misconduct, ${ }^{27}$ and they allow women to create stronger bonds with their children. ${ }^{28}$

Bev Little argues that allowing mothers to bond with their babies only delays the inevitable separation and will cause trauma and have other ill effects on the baby. ${ }^{29}$ But others feel that stronger maternal-fetal attachment is best for both parties. There is evidence that the bond, once formed, is long-lasting. Later in life, there is less drug addiction among children who stayed in the nursery rather than being separated from their mothers. ${ }^{30}$

Another counterargument is that the policies in prison nurseries are not as useful for motherhood outside of the facility; thus, an issue with recidivism occurs because the women are less prepared for motherhood upon release from prison. Prison nursery programs establish methods and procedures for successful motherhood that are unique to operation within correctional environments. Yet, fortunately, parenting classes offered by prisons and jails emphasize sacrifice, self-restraint, and dedicated attention to the baby. These classes aptly apply to motherhood outside of prison. ${ }^{31}$

One incarcerated mother experiencing addiction, Kima, was described as ambivalent toward her pregnancy. "It's something about knowing but not knowing that makes me not accountable or makes me think I'm not accountable," Kima shared..$^{32}$ After the nurse confirmed her pregnancy, she acknowledged fear and knew she would be held accountable to the baby. The occurrence of pregnancy ambivalence is common. ${ }^{33} \mathrm{~A}$ study of a population of prisoners from Rhode Island found that 41 percent of the women expressed ambivalent attitudes about pregnancy. 70 of the women from a population in San Francisco expressed ambivalent or negative attitudes towards pregnancy. ${ }^{34}$ But the ambivalence of some women toward pregnancy is not a reason to prevent women who feel differently from reaping the full benefits of programs that support them during pregnancy.

Another counterargument is that prison is becoming a comfort that women might seek if they are homeless or housing insecure. For example, Evelyn was released from a San Francisco jail after being arrested for using cocaine. She was 26 weeks pregnant and had a four-year-old son in the custody of her aunt. Following her release, she was homeless and using drugs in the streets. She felt that her only hope of keeping her baby safe was to go back to jail. Like Kima, she had been in and out of jail from a young age. She grew accustomed to and dependent on the care provided there. While incarceration can provide a home and a nursery, there is no ethical reason to argue for making prison less comfortable by separating babies and children from incarcerated women. Instead, these facts suggest we are not doing enough for women outside prisons either.

\section{CONCLUSION}

Many experts stress the dearth of research and information on these women and their babies. There is no empirical data to show how big the problem is, but there is evidence that programs providing nursery care for the children of incarcerated women have many benefits. Because the research is not largescale enough, many pregnant women in the prison system are ignored. Many women give birth in unacceptable conditions, and their children are taken from them the moment the umbilical cord is cut. While the US incarcerates too many women, a movement to expand prison nurseries could help new mothers bond with their children. Strong educational programs could aid in lowering the rates of recidivism by providing therapeutic resources for mothers. ${ }^{35}$ 
There is a growing problem of mass incarceration in the US as many women are placed in correctional facilities. Most of these women are convicted of possession or use of illegal substances. ${ }^{36}$ Many women come from disadvantaged backgrounds, poverty, and have experienced addiction. Depriving an expectant mother of adequate care is cruel and irresponsible both to the mother and her innocent child.

The criminal justice system is harming children both mentally and physically. Reform of the system is needed to provide the basic care those children need. Programs like IWP's Wee Ones are necessary for physical, psychological, and social development. A program that offers a place for mothers to raise their babies in the community of other mothers would incentivize and facilitate healthy parental habits. Further programs for mothers who are released from prison would give them valuable resources to keep them from returning and encourage healthy relationships between the mother and the baby.

${ }^{1} \mathrm{Li}, \mathrm{D} . \mathrm{K}$. Video allegedly shows woman giving birth in Denver jail cell alone, with no assistance. Denver: NBC News, 2019.

2 Kajstura, Aleks. "Women's Mass Incarceration: The Whole Pie 2019." Prison Policy Initiative, 29 Oct. 2019, https://www.prisonpolicy.org/reports/pie2019women.html. ("Including those in prisons, jails, and other correctional facilities.")

${ }^{3}$ Swavola, E, K Riley and R Subramanian. "Overlooked: Women and Jails in an Era of Reform." Vera Institute of Justice August 2016.

${ }^{4}$ Sufrin, C. Pregnant Behind Bars: What We Do and Don't Know About Pregnancy and Incarceration Allison Chang. 21 March 2019. Transcript.

${ }^{5}$ Sufrin, C., 2019. (Suffrin expressed that she had seen such practices firsthand working as an OB/GYN for incarcerated women.)

${ }^{6}$ Padilla, M. "Woman Gave Birth in Denver Jail Cell Alone, Lawsuit Says," New York Times, Sep. 1, 2019.

7 Li, D. "Video allegedly shows woman giving birth in Denver jail cell alone, with no assistance," NBC U.S. News, Apr. 29. 2019.

${ }^{8}$ Knittel, A. and C. Sufrin. "Maternal Health Equity and Justice for Pregnant Women Who Experience Incarceration." JAMA Network Open 3.8 (2020). A study in Ontario, Canada, coincided with a study done in Australia.

${ }^{9}$ Sufrin, C., et al. "Pregnancy Outcomes in US Prisons, 2016-2017." p. 803-804.

${ }^{10}$ Sridhar, S., R. Cornish and S. Fazel. "The Costs of Healthcare in Prison and Custody: Systematic Review of Current Estimates and Proposed Guidelines for Future Reporting." Frontiers in Psychiatry 9.716 (2018).

${ }^{11}$ Kifer, M., Hemmens, C., Stohr, M. K. "The Goals of Corrections: Perspectives from the Line" Criminal Justice Review. 1 May 2003

12 Perry, D. M. "Our Long, Troubling History of Sterilizing the Incarcerated." The Marshall Project: Sterilization of Women in Prison 26 July 2017. 
${ }^{13}$ Rachel Roth \& Sara L. Ainsworth, If They Hand You a Paper, You Sign It: A Call to End the Sterilization of Women in Prison, 26 Hastings WOMEN's L.J. 7 (2015); See Skinner v. Oklahoma ex rel. Williamson, 316 U.S. 535 (1942) (procreation considered a fundamental right; fact pattern of male sterilization in prison based on type of crime.)

${ }^{14}$ Sufrin, C., M. D. Creinin, J. C. Chang. "Incarcerated Women and Abortion Provision: A Survey of Correctional Health Providers." Perspectives on Sexual and Reproductive Health. p. 6-11. 23 March 2009.

${ }^{15}$ Kasdan, D. "Abortion Access for Incarcerated Women: Are Correctional Health Practices in Conflict with Constitutional Standards?" Guttmacher Institute. 26 March 2009.

${ }^{16}$ Born Behind Bars. Season 1, Episode 5, "They Can Take Your Baby Away," produced by Luke Ellis, Francis Gasparini, \& Jen Wise, aired on 15 Nov. 2017 A\&E Networks

${ }^{17}$ Bick, J., \& Dozier, M. (2008). Helping Foster Parents Change: The Role of Parental State of Mind. In H. Steele \& M. Steele (Eds.), Clinical applications of the Adult Attachment Interview (pp. 452-470). New York: Guilford Press.

${ }^{18}$ Sroufe, L. A., B. Egeland, E. A. Carlson, W. A. Collins. (2005). The Development of the Person: The Minnesota Study of Risk and Adaptation from Birth to Adulthood. New York: Guilford Press.

${ }^{19}$ Goshin, L. S., \& Byrne, M. W. "Converging Streams of Opportunity for Prison Nursery Programs in the United States." Journal of Offender Rehabilitation. 15 Apr 2009.

${ }^{20}$ Babies Behind Bars. Dirs. W. Serrill and S. O'Brien. 2015. Another IWP pregnant woman is Taylor. At the time of the show, she was pregnant and expecting twins. In interviews throughout the episode, she expressed how her pregnancies in prison had put her in a better mood and felt beneficial to her. She had tried to sign up for the nursery program for her previous pregnancy, but her sentence was too long to get it. Her child was sent to live with a caregiver, and when Taylor was on probation, Taylor's daughter didn't want to be around Taylor. Taylor was so distraught that she messed up and went back, this time, pregnant with twins. After she was reincarcerated, she was able to be accepted into Wee Ones. She expressed to the camera man that the program might help her feel more like a mother so that when she gets out, she will have someone to care for. Taylor, Kara, and many other women depend on their children or their pregnancy for a purpose while behind bars. They relied on their babies to be a boon for them.

${ }^{21}$ Babies Behind Bars. Dirs. W. Serrill and S. O'Brien. 2015.

${ }^{22}$ Corley, C. "Programs Help Incarcerated Moms Bond with Their Babies in Prison." Criminal Justice Collaborative (2018).

${ }^{23}$ Corley, C. "Programs Help Incarcerated Moms Bond with Their Babies in Prison." Criminal Justice Collaborative (2018).

${ }^{24}$ Owen, B. \& Crow, J. "Recidivism among Female Prisoners: Secondary Analysis of the 1994 BJS Recidivism Data Set” Department of Criminology California State University (2006) p. 28

${ }^{25}$ Prison Nursery Programs: Literature Review and Fact Sheet for CT. Diamond Research Consulting, 2012, www.cga.ct.gov/2013/JUDdata/tmy/2013HB-06642-R000401-Sarah Diamond - Director, Diamond Research Consulting-TMY.PDF. 
${ }^{26}$ New York Department of Correction Services (NYDOCS). (1993). Profile of Participants: The Bedford and Taconic Nursery Program in 1992. Albany, NY. Department of Correction Services. Rowland, M., \& Watts, A. (2007). Washington State's effort to the generational impact on crime. Corrections Today. Retrieved September 12, 2007, from http://www. aca.org/publications/pdf/Rowland_Watts_Aug07.pdf.

${ }^{27}$ Carlson, J. R. (2001). Prison nursery 2000: A five-year review of the prison nursery at the Nebraska Correctional Center for Women. Journal of Offender Rehabilitation, 33, 75-97.

${ }^{28}$ Carlson, J.R.

${ }^{29}$ Little, B. "What Happens When a Woman Gives Birth Behind Bars?" A+E Networks, 29 October 2019. $<$ https://www.aetv.com/real-crime/what-happens-when-a-woman-gives-birth-in-jail-or-prison>.

${ }^{30}$ Margolies, J. K., \& Kraft-Stolar, T. When "Free" Means Losing Your Mother: The Collision of Child Welfare and the Incarceration of Women in New York State 1, 9 (Correctional Association of N.Y. Women in Prison Project 2006)

${ }^{31}$ Sufrin, C. Jailcare: Finding the Safety Net for Women Behind Bars. Berkeley: University of California Press, 2017.

32 Sufrin, C. Jailcare: p. 155.

${ }^{33}$ Peart, M. S. \& Knittel, A. K. "Contraception need and available services among incarcerated women in the United States: a systematic review." Contraception and Reproductive Medicine. 17 March 2020

${ }^{34}$ LaRochelle, F., C. Castro, J. Goldenson, J. P. Tulsky, D.L. Cohan, P. D. Blumenthal, et al. "Contraceptive use and barriers to access among newly arrested women." J Correct Health Care. (2012) p. 111-119.

${ }^{35}$ Goshin, L., \& Byrne, M. (2009). "Converging streams of opportunity for prison nursery programs in the United States." Journal of Offender Rehabilitation. 2009. p.271-295.

${ }^{36}$ Elizabeth Swavola, Kristine Riley, Ram Subramanian. Overlooked: Women and Jails in an Era of Reform. New York: Vera Institute of Justice, 2016. 